\title{
THE UNDIFFERENTIATED AFROMONTANE FOREST OF DENKORO IN THE CEN- TRAL HIGHLAND OF ETHIOPIA: A FLORISTIC AND STRUCTURAL ANALYSIS
}

\author{
Abate Ayalew, Tamrat Bekele * and Sebsebe Demissew \\ Department of Biology, Faculty of Science, Addis Ababa University, PO Box 3434 \\ Addis Ababa, Ethiopia. Email: tambek@bio.aau.edu.et
}

\begin{abstract}
The floristic composition and vegetation structure of Denkoro forest, South Wello Zone of Amhara Region, N. Ethiopia, were described during November-December, 2002. A total of 95 sample plots were analysed, and 174 species of vascular plants representing 66 families were recorded. Out of these, 41 species were new records reported for the first time from Wello. Eleven endemic species, which are included in the IUCN Red List categories, have been recorded. Based on the results of vegetation classification, six clusters were recognized and designated as local plant community types: 1) Erica arborea - Hypericum revolutum, 2) Myrsine melanophloeos - Dombeya torrida, 3) Myrsine africana Maesa lanceolata - Prunus africana, 4) Olinia rochetiana - Olea europaea, 5) Olinia rochetiana - Allophylus abyssinicus - Apodytes dimidiata, and 6) Maytenus gracilipes - Teclea nobilis. Structural analysis of the forest showed the density of individuals $>10 \mathrm{~cm}$ DBH to be almost twice as that of individuals with DBH $>20$ $\mathrm{cm}$. A higher proportion of woody individuals (ca. 65\%) fell in the low height classes (i.e., $<12 \mathrm{~m}$ ). Analysis of population structure revealed five patterns, depicting the species dynamics in the forest. When compared with other forests in Ethiopia, Denkoro forest shows similarity to the dry evergreen montane forests of the Central Plateau than those elsewhere.
\end{abstract}

Key words/phrases: Afromontane forest, central plateau, plant community, phytogeography, Wello

\section{INTRODUCTION}

A substantial proportion of the land area in highland Ethiopia was once believed to have been covered by forests. However, evidence to verify this assumption is lacking, and according to Friis (1986) it is difficult to establish the precise extent of forest coverage in Ethiopia. Available statistics do not distinguish between the natural high forest, secondary forest and other serial stages in forest regrowth. Any estimation of the past coverage, (e.g., Logan, 1946) is far from being realistic, as it has so far to rest on estimates based on the distribution of rainfall and forest relic patches.

The reduction in forest vegetation was due to climatic changes and human activities (Hamilton, 1974). In the latter case, clearing for cultivation, burning to create pasture lands, and improper cutting practices have reduced the forest area to a small fraction of the total area of the country.

Destruction of forest in the Afromontane zone of Wello, north eastern Ethiopia, has been documented through carbon dating of charcoal as far back as 2450 BP (Hurni, 1985). The forest has been replaced by cultivated fields and by various types of shrub land and grassland (Pichi-Sermolli, 1957; Kebrom Tekle et al., 1997).
In order to maintain the ecological equilibrium of the environment and meet the forest resource requirements of the population, collection of scientific information on the composition, structure and distribution of the species becomes a primary activity in areas where this has not been achieved. Recent studies into the flora and vegetation of South Wello include those that dealt with the ecological rehabilitation of degraded hill slopes (Kebrom Tekle, 1998), flora (Sebsebe Demissew, 1998), and plant population dynamics of selected species (Tesfaye Bekele, 2000).

Denkoro forest is one of the forests that had been designated as a National Forest Priority Area (NFPA) in the country (EFAP, 1994). However, no study so far has been carried on the vegetation of Denkoro forest. This has become a serious handicap for the management and rational utilization of the forest resources of the area. Therefore, species documentation, classification and description of the forest have been found timely. The present study is conducted with the following objectives in mind:

$>$ To analyse the floristic composition of the forest,

$>$ To analyse the vegetation structure of the forest, 
To classify the forest vegetation into plant community types,

To make phytogeographical comparisons with other forests in Ethiopia,

$>$ To make some recommendations on the management and conservation of the forest vegetation.

\section{MATERIALS AND METHODS}

\section{The study area}

The study site is located in the South Wello Zone (Amhara Regional State), and situated approximately between $10^{\circ} 47^{\prime}-10^{\circ} 50^{\prime} \mathrm{N}$ and $38^{\circ} 35^{\prime}-38^{\circ}$ $42^{\prime} \mathrm{E}$ (Fig. 1). According to EFAP (1994) the land area of Denkoro forest is 8000 ha, which makes it the smallest forest among the National Forest Priority Areas (NFPA) in Ethiopia. The study area is generally characterized by rough topography with mountains, deeply incised valleys, escarpments and plateaus. South Wello, which ranges from 1500 to $3500 \mathrm{~m}$ a.s.l (MoPED, 1993), is in most parts covered by volcanic rocks mainly basalts of Tertiary age (Anonymous, 1988, cited in Tesfaye Bekele, 2000).

The natural vegetation of the study area had been broadly classified as Juniperus procera forest or "dry evergreen montane forest" with J. procera and/or Olea europaea ssp. cuspidata as the dominant species (Mesfin Tadesse, 1990; Friis, 1992).

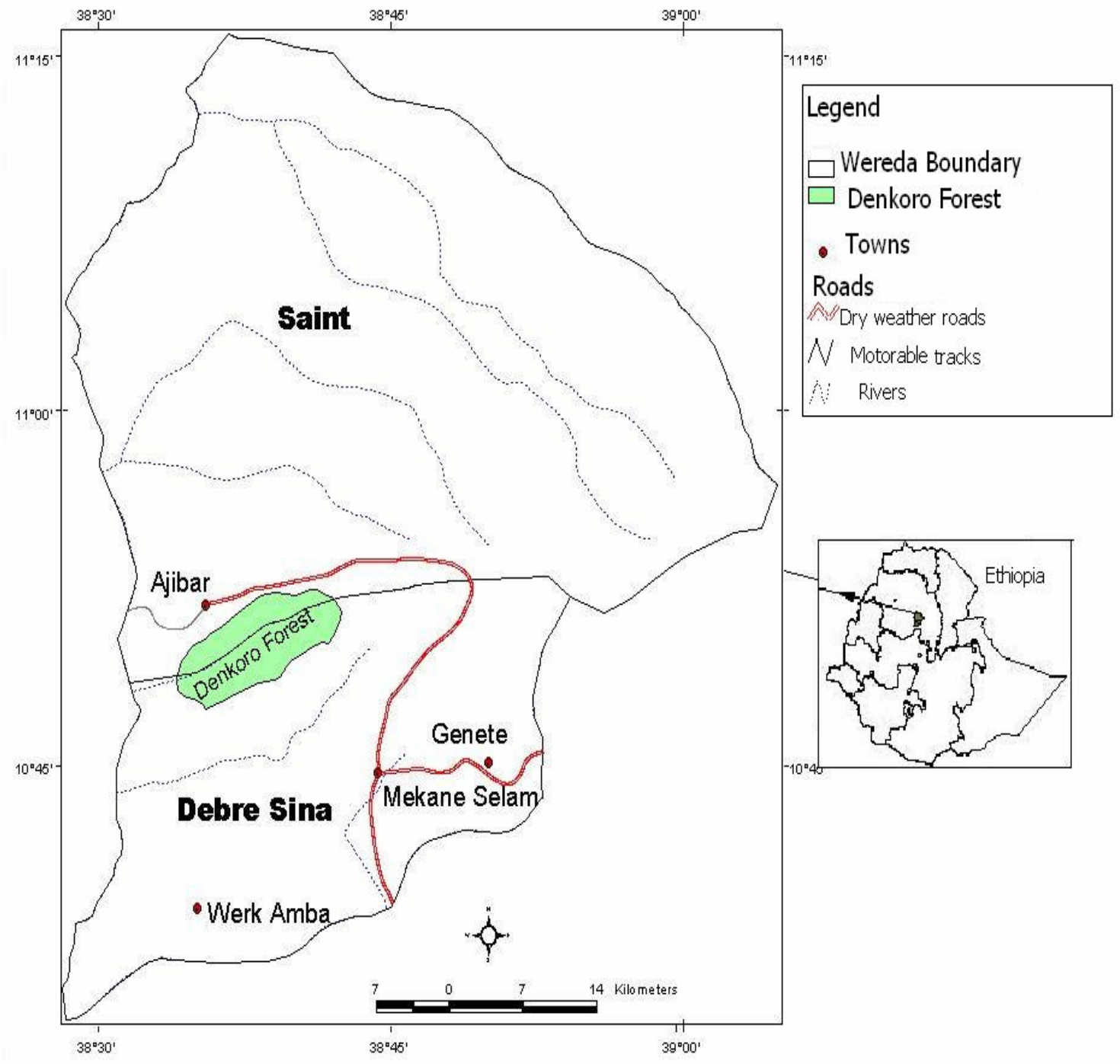

Fig. 1. Location map of the study area. 
The distribution of rainfall in South Wello is bimodal, characterized by a prolonged wet season from June to September (big rains), and a short season from March to April (small rains). The small rainy season is erratic and highly variable. There is a long dry period from the beginning of November to the end of February, and a short dry spell in May. The climatic diagram of Mekane Selam station, about $20 \mathrm{~km}$ from the forest, is presented in Fig. 2.

Mekane Selam (2600)

[10] $16.1^{\circ} 933$

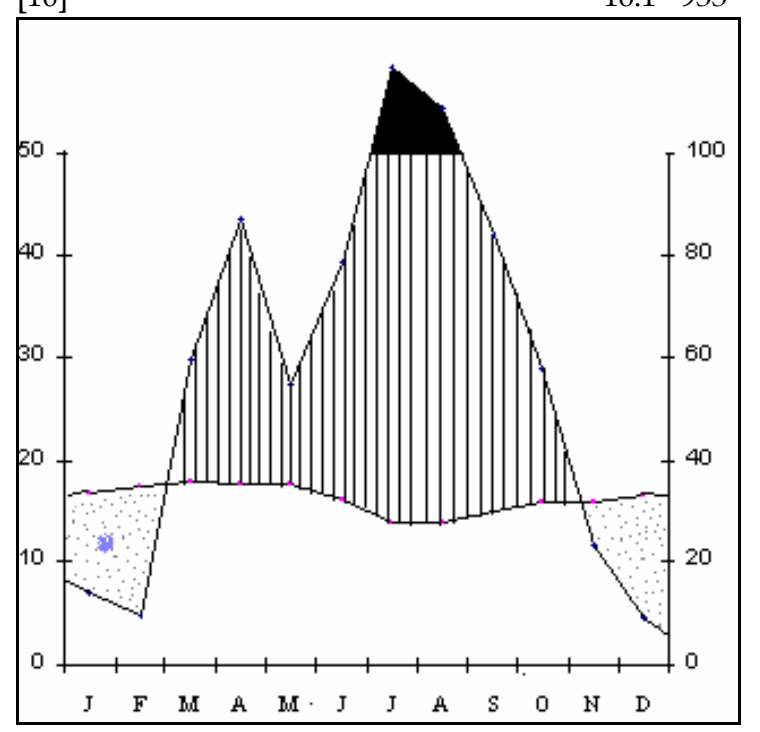

Fig. 2. Climatic diagram for the town of Mekane Selam, (Drawn after Walter, 1985). Source of climate data: National Metrological Service Agency).

\section{Floristic data collection}

A reconnaissance survey of Denkoro forest was made between November 10 and 12/ 2002 in order to obtain an impression of the floristic diversity of the vegetation. Actual field data were collected from November 13 to December 6, 2002. A total of 95 relevés were analysed from the whole forest. Sample plots were systematically selected following the Braun-Blanquet approach as described in van der Maarel (1979).

Trees and shrubs were sampled in $5 \mathrm{~m} \times 25 \mathrm{~m}$ quadrats, while herbaceous and graminoid species were analyzed in $1 \mathrm{~m} \times 1 \mathrm{~m}$ quadrats that are subjectively placed within the larger quadrat. A complete list of trees, shrubs and herbs was made from each plot. Percent cover value was estimated for each species and later converted to the BraunBlanquet 1-9 scale as modified by van der Maarel (1979).

Additional plant species occurring out of the plots, but inside the forest, were recorded.
Climbers were noted as present when encountered. Notes were also made on the total number of dead standing trees, stumps and logs in the plot. At each sampling site, altitude was measured using Pretzel digital altimeter, and aspect using Suunto M-3D Leader Compass.

Plant specimens in each quadrat were recorded, along with their vernacular names when available, and collected and pressed for later identification. Identification was made at the National Herbarium, Addis Ababa University, following the Flora of Ethiopia (Hedberg and Edwards, 1989; 1995; Edwards et al., 1995; 1997; 2000). Voucher specimens are kept in the National Herbarium.

\section{Structural data collection}

All individuals of trees and shrubs with a diameter at breast height (DBH) greater than $2 \mathrm{~cm}$, and height greater than $2 \mathrm{~m}$ were measured for height and DBH. Individuals with DBH less than 2 $\mathrm{cm}$, and height less than $2 \mathrm{~m}$ were counted. Height measurement was done with Suunto Height Meter and DBH with measuring Caliper and Meter tape. Where slope, topography and/or crown structure made it difficult to use the height meter, heights were estimated visually. If the tree branched at about breast height, the diameter was measured separately for the branches.

\section{Data analysis}

Releve's were grouped into clusters with the aid of the program TWINSPAN (Hill, 1979). The clusters were further refined in a synoptic table where each column represents a community type, and species occurrences were summarized by synoptic cover-abundance values. Synoptic values are the products of the species' frequency and average cover-abundance values (van der Maarel et al., 1987). The clusters were designated as local plant community types and given names after one, two or three dominating and/or characteristic tree and shrub species as selected by their synoptic value.

Floristic comparison between the vegetation of Denkoro and other nine forests from Ethiopia was made based on the presence/absence of tree and shrub species. The similarity index used is Sorenson's similarity coefficient: $2 c /(a+b)$; where " $\mathrm{c}$ " is the number of species shared by the forests compared, "a" is the number of species in one forest, " $b$ " is the number of species in the other forest.

The structure of the forest was described through the analyses of tree density, girth diame- 
ter, height, and basal area. Tree density and basal area values were computed and described on a hectare basis. The diameter at breast height (DBH) was classified into six DBH classes (i.e., $10-20 \mathrm{~cm}$, $20-50 \mathrm{~cm}, 50-80 \mathrm{~cm}, 80-110 \mathrm{~cm}, 110-140 \mathrm{~cm},>140$ $\mathrm{cm})$, and the percentage distribution of individuals in each class was calculated. Tree height was also classified into nine classes (i.e., 6-9 $\mathrm{m}, 9-12$ m, 12-15 m, 15-18 m, 18-21 m, 21-24 m, 24-27 m, 27-30 m, >30 m), and percentage distribution of individuals in each class was calculated. The vegetation of Denkoro forest was later compared with selected Afromontane forests of the central plateau based on the above structural attributes.

\section{RESULTS}

\section{Floristic composition}

A total of 174 species of vascular plants representing 66 families were recorded from the forest (a complete species list can be provided upon request). The floristic and structural analysis was based on 109 species that were collected from within the quadrats. Of the species collected, $62.4 \%$ were herbs, $14.5 \%$ trees, $3.5 \%$ trees/shrubs and $19.6 \%$ were shrubs. Of the total species, dicots constituted $80.9 \%$, monocots $17.9 \%$, and Pteridophytes $1.2 \%$.

Six climber species were recorded from the families Asclepiadaceae, Ranunculaceae, Convolvulaceae, Cucurbitaceae, Phytolaccaceae, and Urticaceae. A species from a lichen genus, Usnea, has also been recorded.

\section{Vegetation classification}

Six plant associations, designated as 'community types', were recognized from the vegetation analysis. A list of the community types along with the synoptic cover-abundance values of the species is given in Table 1. One releve, which did not fit into any cluster was considered to represent a fragmentary development, and was excluded from subsequent analysis. The following is a description of the community types identified from the forest.

\section{Erica arborea-Hypericum revolutum type}

The Erica arborea-Hypericum revolutum type is found from 2990 to 3340 m.a.s.l. The characteristic species in the tree layer is Erica arborea. Hypericum revolutum and Myrsine melanophloeos are the other tree species in this layer. Discopodium penninervium is the character species in the shrub layer. Achyranthes aspera is the dominant species in the herb layer. Alchemilla abyssinica, Festuca abyssinica, and Thymus schimperi are the characteristic species in the field layer. Associated species in the field layer include Sporobolus pyramidalis, Satureja simensis, Festuca macrophylla, Cerastium octandrum, Luzula abyssinica and Carex steudneri. All Erica arborea individuals had been noted to possess a high coverage of the epiphytic lichen of the genus Usnea.

\section{Dombeya torrida-Myrsine melanophloeos type}

This community type is distributed between 2740 and 3165 m.a.s.l. Myrsine melanophloeos is the dominant species in the tree layer. Dombeya torrida is the character species and Hypericum revolutum and Hagenia abyssinica are the associated tree species in this layer. There was no prominent species in the shrub layer but a few individuals of Myrsine africana have been encountered. Streblochaete logiarista is the characteristic species in the field layer. Achyranthes aspera is the dominant species while Carex steudneri, Cynoglossum coeruleum, Geranium arabicum, Ranunculus oreophytus, Rubus steudneri, Sanicula elata, Stachys alpigna, Stachys aculeolata, Solanum margintum and Carex steudneri constitute the associated species in the field layer.

\section{Maesa lanceolata-Prunus africana type}

This community type was distributed from 2770 to 2860 m.a.s.l. The dominant tree species in this type is Myrsine melanophloeos. Maesa lanceolata and Prunus africana are the characteristic tree species. Nuxia congesta and Bersama abyssinica are the associated trees species in this community type. Allophylus abyssinica and Juniperus procera have been recorded in this type but in smaller numbers. Myrsine africana is the characteristic species in the shrub layer. The field layer is dominated by Achyranthes aspera.

\section{Olinia rochetiana-Olea europaea type}

This community type prevails between 2460 and $2765 \mathrm{~m}$ a.s.l. Olinia rochetiana and Olea europaea are the dominant tree species in the tree layer. The associated tree species in this community type include Apodytes dimidiata, Bersama abyssinica and Nuxia congesta. Discopodium penninervium, Dovyalis abyssinica, Maytenus arbutifolia were the species recorded from the shrub layer. Achyranthes aspera is the dominant species in the herb layer, while Kalanchoe petitiana and Mimulopsis solmsii are the associated species in the field layer. 


\section{Olinia rochetiana-Allophylus abyssinicus-} Apodytes dimidiata type

This community type is distributed at the altitudes ranging from 2350 to $2660 \mathrm{~m}$ a.s.l. The dominant tree species in this type are Olinia rochetiana and Apodytes dimidiata. Allophylus abyssinicus is a characteristic tree species in this community type, while Bersama abyssinica, Olea europaea ssp. cuspidata, and Nuxia congesta are the associated species. Ekebergia capensis, Myrsine melanophloeos, Myrica salicifolia, Prunus africana, and Scolopia theifolia were rare in this community. Clerodendron alatum is the characteristic shrub species. Maytenus gracilipes ssp. arguta, Rosa abyssinica and Dovyalis abyssinica were rare in occurrence in the shrub layer. Achyrospermum schimperi is a characteristic herb species in the field layer whereas Achyranthes aspera is the associated species.

\section{Maytenus gracilipes-Teclea nobilis type}

This community type is distributed from 2330 to $2445 \mathrm{~m}$ a.s.l. The characteristic tree species in this community is Teclea nobilis. The shrub layer is dominated by Maytenus gracilipes. Cyperus dichroostachys and Snowdenia petitiana are the characteristic species in the herb layer whereas Achyranthes aspera is the dominant one. Associated species in the field layer include Mimulopsis solmsii and Kalanchoe petitina.

\section{Vegetation structure}

\section{Density}

The density of all trees in Denkoro forest was 526 individuals per hectare for individuals with DBH $>10 \mathrm{~cm}$, and 285 individuals per hectare for individuals with DBH $>20 \mathrm{~cm}$. The ratio of DBH $>10$ $\mathrm{cm}$ to $\mathrm{DBH}>20 \mathrm{~cm}$ was very high (i.e., 1.9), indicating a prevalence of small sized individuals in the forest. As indicated by Grubb et al. (1963), this ratio, described as $a / b$, is taken as a measure of the size class distribution.

A comparison of the density of trees in Denkoro forest with that of other dry Afromontane forests of the central plateau of Ethiopia is given in Table 2. Denkoro forest has the highest tree density for individuals with $\mathrm{DBH}>20 \mathrm{~cm}$, and ranks second for individuals with DBH $>10 \mathrm{~cm} \mathrm{DBH}$. On the other hand, Chilimo forest had the highest tree density for individuals with DBH $>10 \mathrm{~cm}$.

Table 1. Synoptic cover-abundance values for species having a value of $>1.0$ in at least one community type.

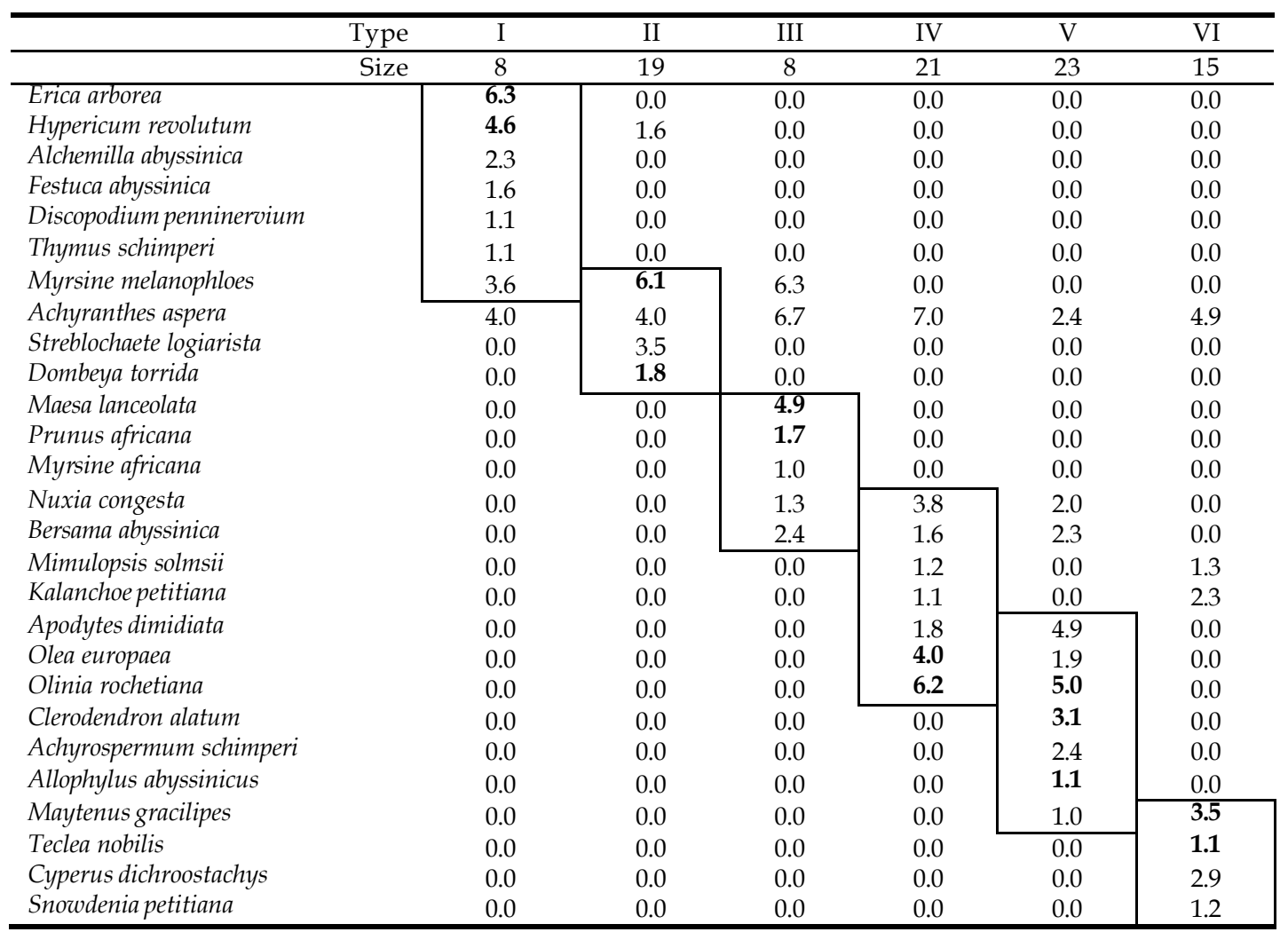

* Values in bold refer to occurrences as characteristic/dominant species. 
Table 2. Comparison of tree density (no./ha) of Denkoro forest with other dry Afromontane forests of the Central Plateau of Ethiopia.

\begin{tabular}{lccc}
\hline Forest & $\begin{array}{c}\mathrm{DBH}> \\
10 \mathrm{~cm}(\mathrm{a})\end{array}$ & $\begin{array}{c}\mathrm{DBH}> \\
20 \mathrm{~cm}(\mathrm{~b})\end{array}$ & $\mathrm{a} / \mathrm{b}$ \\
\hline Denkoro & 526 & 285 & 1.9 \\
Chilimo* $_{\text {Menagesha* }}^{*}$ & 638 & 250 & 2.6 \\
Wof-Washa* $^{*}$ & 384 & 208 & 2.3 \\
\hline
\end{tabular}

Note: * Source of information is Tamrat Bekele (1993).

\section{Tree height and diameter}

The distribution of individuals in different height classes is shown in Fig. 3. A significant proportion of the individuals in Denkoro forest (i.e., $>65 \%$ ) is found in the height classes $6-12 \mathrm{~m}$. Only a very small proportion of the individuals (i.e., 3\%) attain heights of $21 \mathrm{~m}$. The percentage distribution of individuals among the DBH classes is presented in Fig. 4. Most of the individuals, i.e., about $97 \%$, were in the DBH class $<50 \mathrm{~cm}$, and a very small proportion (i.e., $0.6 \%$ ) attained $\mathrm{DBH}$ greater than $110 \mathrm{~cm}$.

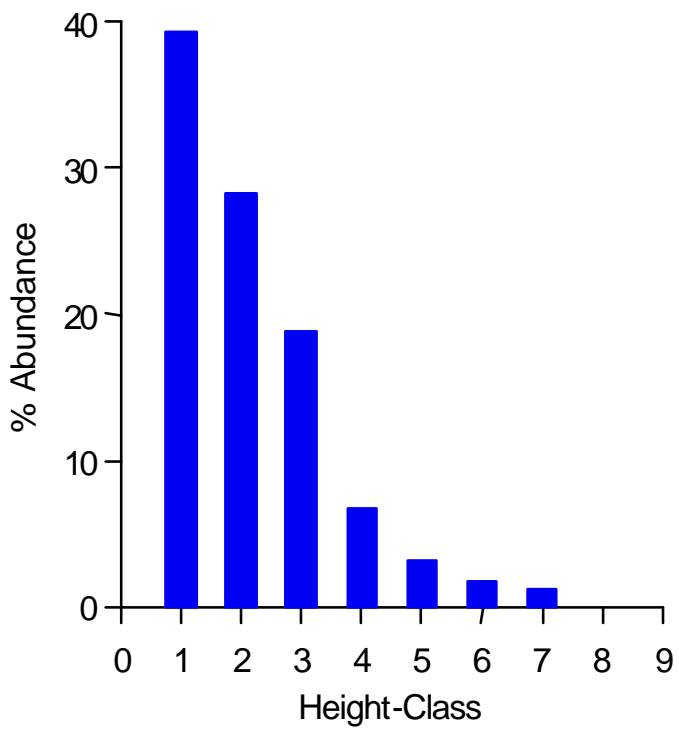

Fig. 3. Percentage distribution of individuals in height classes (m): 1) 6-9, 2) 9-12, 3) 12-15, 4) 15-18, 5) 18-21, 6) 21-24, 7) 24-27, 8) 27-30.

\section{Basal area}

The total basal area calculated for Denkoro forest is $45 \mathrm{~m}^{2} /$ ha. Block diagrams depicting frequency distribution of trees among DBH classes are presented in Fig. 5. Most of the trees are small sized as shown by the peak in basal area in the lowest DBH classes (i.e., $<50 \mathrm{~cm}$ ). Individuals that belong to higher DBH classes are few in number, but their contribution to the total basal area is significant.

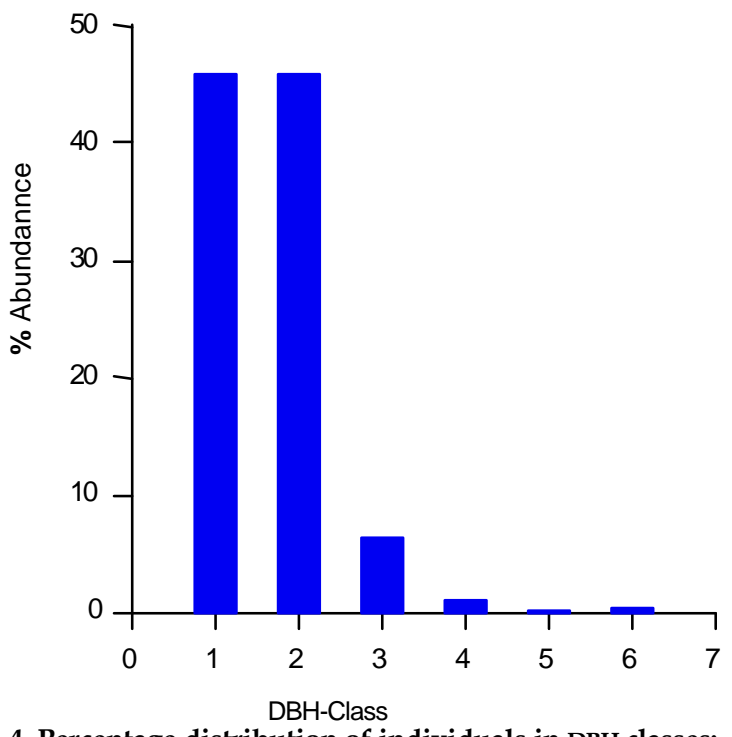

Fig. 4. Percentage distribution of individuals in DBH classes: 1) $10-20 \mathrm{~cm}, 2) 20-50 \mathrm{~cm}, 3) 50-80 \mathrm{~cm}, 4) 80-110 \mathrm{~cm}, 5)$ $110-140 \mathrm{~cm}, 6)>140 \mathrm{~cm}$.

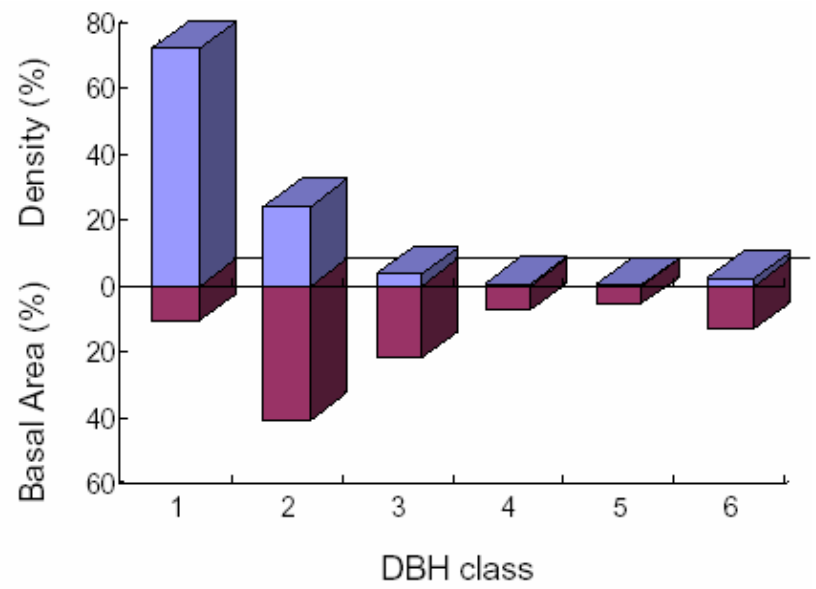

Fig. 5. Frequency distribution of individuals in DBH classes (all trees included) in Denkoro forest. 1, $<20 \mathrm{~cm}, 2$, $20-50 \mathrm{~cm}, 3,50-80 \mathrm{~cm}, 4,80110 \mathrm{~cm}, 5,110-140 \mathrm{~cm}, 6$, $>140 \mathrm{~cm}$ ). Blocks above the 0-line: figures based on relative DBH (\%); blocks below the 0line: figures based on relative basal area $(\%)$.

The basal area and density distribution of six species, selected based on the basis of a high importance value index (IVI) is shown in Table 3. These species contribute to more than $50 \%$ of the total basal area, and $70 \%$ of the tree density of the forest. However, none of the six major species shows an overriding dominance over the others in terms of basal area. 
Table 3. Basal area and density of the six most important tree species in Denkoro forest.

\begin{tabular}{lllll}
\hline \multirow{2}{*}{ Species } & \multicolumn{3}{c}{ Basal area } & \multicolumn{2}{c}{ Density } \\
\cline { 2 - 5 } & $\mathrm{m}^{2} / \mathrm{ha}$ & $\%$ & Stem/ha & $\%$ \\
\hline Myrsine melanophloeos & 5 & 11.1 & 350.8 & 34.5 \\
Erica arborea & 2 & 4.4 & 159.8 & 15.8 \\
Olinia rochetaina & 5.9 & 13.0 & 99.7 & 9.8 \\
Apodytes dimidiata & 5.3 & 11.9 & 28.8 & 2.8 \\
Olea europaea & 4.41 & 9.8 & 30.7 & 3 \\
Nuxia congesta & 2.3 & 5.1 & 46.1 & 4.5 \\
\hline Total & 24.91 & 55.2 & 715.9 & 70.4 \\
\hline
\end{tabular}

\section{Species population structure}

Five generalized patterns emerge from the analysis of the population structure of 25 selected species. An inverted ' $\mathrm{J}$ ' type curve representing good reproduction and recruitment (e.g., Erica
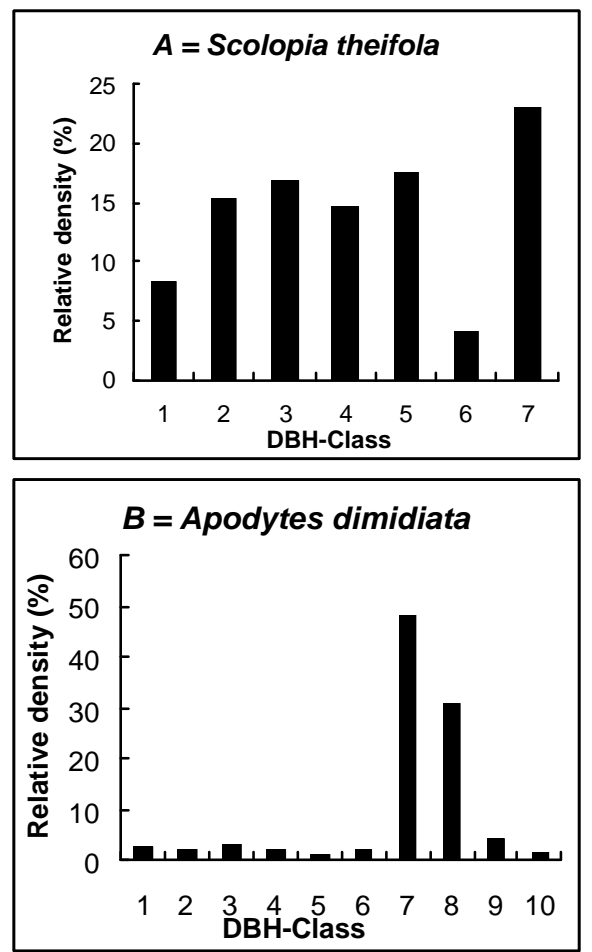

arborea) is shown by Type I curves (Fig. 6). Type II curves indicating a decline in the lowest size class, but good recruitment and establishment in other classes is portrayed by Scolopia theifolia. Type III curves represent intensive harvesting of small and medium sized individuals, and a dwindling population as shown by Apodytes dimidiata. Type IV curves indicate good reproduction and good recruitment, but selective cutting of individuals of intermediate sizes as observed in Myrsine melanophloes. Pattern V curves depicting poor reproduction and complete absence of individuals in intermediate classes, as exemplified by Hagenia abyssinica for instance, indicate a vanishing population.
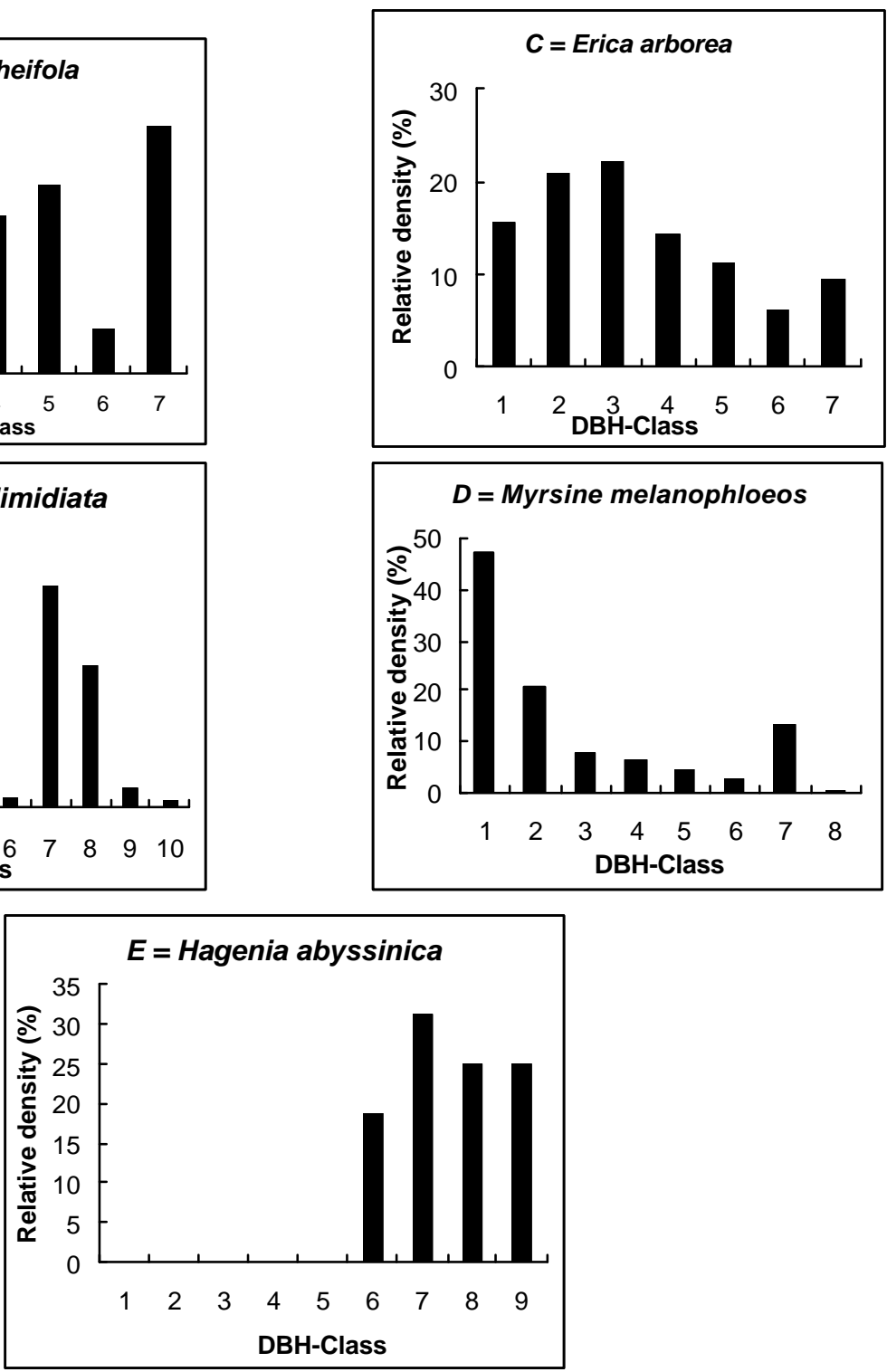

Fig. 6. Five representative patterns of frequency distribution of tree density values over DBH classes in the Denkoro forest. DBH class 1, 2-5 cm; 2, 5-8 cm; 3, 8-11 cm; 4, 11-14 cm; 5, 14 - $17 \mathrm{~cm} ; 6,17-20 \mathrm{~cm} ; 7,20-50 \mathrm{~cm} ; 8,50-80 \mathrm{~cm} ; 9,80-110$ $\mathrm{cm} ; 10,>110 \mathrm{~cm}$. 


\section{DISCUSSION}

\section{Floristic description}

Out of the 174 species identified in the present study, 41 are new records not previously reported from Wello. The forest contains 12 endemic species which are in the IUCN Red List categories. These are Acanthus sennii, Anthoxanthum aethiopicum, Conyza spinosa, Cynoglossum coeruleum, Festuca macrophylla, Kalanchoe petitiana, Kniphofia foliosa, Laggera tomentosa, Satureja paradoxa, Stachys alpigena, Thymus schimperi, and Urtica simensis.

Eight indicator species for forest disturbance have been recorded from the forest. These include Asparagus africanus, Commelina africana, Croton macrostachyus, Cyathula cylindrica, Euphorbia ampliphylla, Kalanchoe petitiana, Phytolacca dodecandra, and Sanicula elata.

The Erica arborea-Hypericum revolutum community type prevails at very high elevations forming a distinct community towards the upper edge of the forest. Individuals of Erica arborea diminish in stature towards the upper limit of their distribution, and merge with the Afroalpine vegetation at about $3500 \mathrm{~m}$ a.s.l.

The vicinity of this plant community to human settlements has subjected it to high anthropogenic influences. It is customary for people from the surrounding villages to take cattle into the forest every evening for grazing, and return late at night holding clusters of firewood to serve as torch. The most preferred species for this are Erica arborea and Hypericum revolutum. According to local informants, most of the harvesting, particularly of Erica arborea, took place during the government transition in 1991 when prisoners, that were kept captive inside a large cave located in the forest, used the species extensively for fire wood.

The prevalence of abundant seedlings of Myrsine melanophloeos, Hypericum revolutum, and Erica arborea in this community obviously indicates that this community is regenerating and may persist in the future, provided appropriately managed.

The Myrsine melanophloeos - Dombeya torrida community type was characterized by medium sized trees with more or less interlocked canopies. Climbers covered some trees, and the community is dotted with some stumps, a large number of uprooted logs, and dead stands of trees, indicative of the magnitude of disturbance. The ground layer is covered with a thick layer of litter that is in different stages of decay. This will create a suitable condition for the rapid circulation of nutrients between the soil and the vegetation.
Myrsine melanophloeos and Hypericum revolutum showed better reproduction in this community, but it is the former, which showed a better recruitment. This is partly due to its good regeneration potential under tree canopies, and its un-palatability to herbivores. Only medium sized and old individuals of Hagenia abyssinica and Dombeya torrida were present, indicating that they are critically endangered. This is especially true for the former, whose floral parts are widely used in traditional medicine to eliminate tapeworm in humans.

Myrsine melanophloeos and Maesa lanceolata showed very good regeneration in the third community type (.e., Maesa lanceolata - Myrsine africana - Prunus fricana community type). Some seedlings of Myrsine africana and Bersama abyssinica were also encountered. On the other hand, no young trees of Dombeya torrida, Prunus africana, Nuxia congesta and Hagenia abyssinica were observed.

Species of Myrsine melanophloeos, Discopodium penninervium and Bersama abyssinica were regenerating abundantly in the Olinia rochetiana Olea europaea community type. On the other hand, Myrsine africana, Maytenus arbutifolia, Dovyalis abyssinica, Scolopia theifolia, Ekebergia capensis and Clerodendron alatum showed poor regeneration, while Olinia rochetiana, Juniperus procera, Olea europaea ssp. cuspidata, Hagenia abyssinica, Nuxia congesta and Prunus africana showed no sign of regeneration at all.

This could be due to either the species' inability to regenerate under the parent plant, or because of total failure in regeneration. If the former is the case, this implies that the species requires special conditions to facilitate its germination. If it is the latter, for instance, as in the case of Hagenia abyssinica, then it would mean that the species' future is bleak, indicating possible extinction from the community. Some stumps, few logs and dead but standing individuals of Erica arborea, Olinia rochetiana, Juniperus procera, Olea europaea ssp. cuspidata and Hagenia abyssinica were notable.

Species such as Bersama abyssinica, Clerodenderon alatun, Myrsine melanophloeos and Maytenus gracilipes showed good regeneration in the Olinia rochetiana - Allophylus abyssinicus - Apodytes dimidiata community type. The fact that Apodytes dimidiata, currently one of the dominant species in the community, is poorly regenerating indicates that its ecological influence (i.e., impact on the community's structure and dynamics) will be bleak in the future.

Some old individuals and several saplings of Podocarpus falcatus were observed in the Maytenus 
gracilipes - Teclea nobilis community type at lower altitudes. However, the bark of this rare tree species in the forest is being harvested for its medicinal use (as communicated by the local people), thus calling for an appropriate management plan to ensure its sustainable use in the future.

Results of similarity analyses (Table 4) indicate Denkoro forest to have the highest affinity with the forests of Chilmo and Menagesha, and lesser resemblance to the forests of Wof Washa, Jibat, (all four located in the central plateau of Ethiopia), and Harenna (situated in the south eastern highlands). Denkoro forest shows the least resemblance to the south western forests of Ethiopia as it is found in a different climate regime compared to the south western forests: the former is classified as a dry afromontane forest while the later is a humid broad leaved forest. Variability in the amount of annual precipitation accounts for the floristic differences observed in these forests.

Table 4. Floristic similarities between Denkoro forest (with 58 species) and 9 other forests from Ethiopia.

\begin{tabular}{llll}
\hline Forest & $\mathrm{a}$ & $\mathrm{b}$ & $\mathrm{SI}$ \\
\hline South Western Eth. Forest $^{1}$ & 88 & 18 & .24 \\
Harenna forest $^{2}$ & 85 & 30 & .42 \\
Jemjem forest $^{3}$ & 67 & 21 & .33 \\
Shrub land of South west Shewa $^{4}$ & 55 & 21 & .37 \\
Tree Shrub layer of South Wello $^{5}$ & 43 & 21 & .41 \\
Jibat $^{6}$ & 52 & 26 & .47 \\
Chilmo $^{6}$ & 31 & 26 & .58 \\
Menagesha $^{6}$ & 31 & 26 & .58 \\
Wof Washa $^{6}$ & 29 & 21 & .48 \\
\hline
\end{tabular}

Note: ' $a$ ', number of species used for comparison, ' $b$ ', number of common species with Denkoro forest, and SI, similarity index.

Sources: ${ }^{1}$ (Kumlachew Yeshitila and Tamrat Bekele, 2002); ${ }^{2}$ (Lisanework Nigatu, 1987); ${ }^{3}$ (Hailu Sharew, 1982); ${ }^{4}$ (Zerihun Woldu and Backeus, 1991); ${ }^{5}$ (Kebrom Tekle et al., 1997); ${ }^{6}$ (Tamrat Bekele, 1993).

\section{Structural description}

The results of the structural analyses of the natural vegetation of Denkoro forest reveal that it is in a stage of secondary development, with very close resemblance to the forests of Chilimo and Menagesha that have been described by Tamrat Bekele (1993). The ratio of individuals with DBH > $10 \mathrm{~cm}$ to $\mathrm{DBH}>20 \mathrm{~cm}$ (i.e., a/b ratio) in the forests of Denkoro, Chilimo and Menagesha resemble one another (see Table 2). Small sized woody species predominate in all the three forests as revealed by the high $a / b$ ratio. That the forests had been exposed to a history of heavy deforestation is observable in the absence of large individuals.
Distribution of individuals in different height classes also reveals a similar trend in these forests (Table 5).

The basal area for Denkoro forest (i.e., $45 \mathrm{~m}^{2} / \mathrm{ha}$ ) showed more resemblance to figures reported for the forests of Menagesha and Chilimo than to WofWasha (see Tamrat Bekele, 1993; 1994). The basal area of these forests is $36.1 \mathrm{~m}^{2} / \mathrm{ha}, 30.1 \mathrm{~m}^{2} /$ ha and $101.8 \mathrm{~m}^{2} /$ ha, respectively.

Table 5. Comparison of percentage distribution of individuals in height classes in Denkoro and three other Afromontane forests.

\begin{tabular}{lllll}
\hline $\begin{array}{l}\text { Height class } \\
(\mathrm{m})\end{array}$ & Chilimo & Menagesha & $\begin{array}{l}\text { Wof- } \\
\text { Washa }\end{array}$ & Denkoro \\
\hline $6-9$ & 42.1 & 38.5 & 23.3 & 39.3 \\
$9-12$ & 30.8 & 32.0 & 21.3 & 28.3 \\
$12-15$ & 15.3 & 10.8 & 13.7 & 18.9 \\
$15-18$ & 7.5 & 11.0 & 13.1 & 6.7 \\
$18-21$ & 3.4 & 2.2 & 6.1 & 3.2 \\
$21-24$ & 1.1 & 2.2 & 1.6 & 1.7 \\
$24-27$ & - & 1.0 & 8.0 & 1.2 \\
$27-30$ & - & $<1$ & 8.0 & $<1$ \\
$>30$ & - & 2.0 & 4.8 & - \\
\hline
\end{tabular}

Two major groups of woody species can be recognized based on the patterns of species population structure. The first group consists of species that are capable of regenerating in the forest under-story. These include species such as Myrsine melanophloeos, Hypericum revolutum, Ekebergia capensis, Discopodium pennineroum, Myrsine africana, Maesa lanceolata, and Bersama abyssinica. Species such as Hypericum revolutum and Ekebergia capensis, having a good regeneration were poorly represented in the seedling and sapling layer because they were preferred by grazers and were suitable for browsing too.

The second group includes those species that are very big and old trees with difficulty in regenerating in the forest under-storey. These include species such as Hagenia abyssinica, Juniperus procera and Olea europaea. As a result, these species are critically endangered and might face possible extinction in this forest. This is even more so especially for the species of Hagenia abyssinica, where the old trees have started to die back, and some individuals were completely dried and uprooted.

\section{Phytogeographical description}

The altitudinal range of Denkoro forest is from 2300 to $3500 \mathrm{~m}$ a. s. 1., and it is known that altitude has a decisive role on the distribution of vegetation on East African Mountains (Hedberg, 1951; Lind 
and Morrison, 1974; Tewolde Berhan Gebre Egziabher, 1989). Three vegetation belts were described as characteristic for East African mountains based on altitude (Hedberg, 1951). These are the Afromontane forest belt, the Ericaceous belt and the Alpine belt. The Afromontane forest belt, and the Ericaceous belt are represented in Denkoro forest. The Afromontane forest belt is further subdivided into three zones (Hedberg, 1951); the Afromontane rain forest zone, the Bamboo zone and the Hagenia Hypericum zone. The Hagenia - Hypericum zone has been detected and described from Denkoro forest, while the former two are absent.

The Afroalpine belt has neither been investigated in the present study, nor cited in any other literature, but it is recognizable above the Ericaceous zone (sub-Afroalpine belt) in Denkoro forest. This vegetation merits future investigation, as it would enrich our current knowledge on the floristics of the belt in particular, and the ecosystem at large.

Among the seven forest types described from Ethiopia by Friis (1992), Denkoro forest fits the description given to the undifferentiated Afromontane forests. However, the forest contains elements of both transitional rain forest, and undifferentiated Afromotane forest as well, consisting of dominant tree species like Juniperus procera, Olea europaea ssp. africana, Croton macrostachyus, Ficus sur and Maesa lanceolata. Species characteristic of moist forests (e.g., Prunus africana), have also been identified. It was also noted that Ekebergia capensis and Acacia abyssinica existed as relics in a dispersed manner in areas adjacent to the forest.

From the present analysis, therefore, it can be concluded that the forest is characterized more by species of the undifferentiated ones, although some elements of Afromontane rain forests are present. Only one of the species (Ficus sur) is a GuineoCongolian floral element. According to Tamrat Bekele (1993) Ficus sur is found in specialized habitats such as along river courses, and in Denkoro forest it has been observed as occurring in a marshy plain, at an altitude of $2300 \mathrm{~m}$ a.s.l. The presence of this species in Denkoro forest has to do with the close proximity of the forest to the lowland floral region, and the presence of suitable habitats for its growth at lower altitudes in the forest.

Prunus africana, typical of moist montane forests (Lind and Morrison, 1974), has been recorded from this forest. This marks the northern latitudinal limit so far described for the species in Ethiopia. On the other hand, Denkoro forest includes Afromontane endemics such as Juniperus procera, Olea europaea ssp. africana, Hagenia abyssinica, Podocarpus falcatus, Apodytes dimidiata, Ilex mitis, Myrsine melanophloeos and Olinia rochetiana. The species mentioned as dominant tree species by Lind and Morrison (1974), except Olea europaea ssp. africana and Maesa lanceolata, and Friis (1992) were rare in the forest.

In addition to the Afromontane endemics, other species belonging to connecting elements have been identified from Denkoro forest. These include the 'ecological transgressor' Ekebergia capensis, and 'forest pioneer connecting species' like Maesa lanceolata and Bersama abyssinica. The former can be found dispersed over a wider geographical area, while the latter two are found in disturbed habitats along forest edges.

Some of the montane forest species listed from Denkoro forest have also been recorded in shrub land vegetation of the central plateau of Ethiopia that had been described by Zerihun Woldu and Backeus (1991). These species include Erica arborea, Juniperus procera, Olea europaea, Pittosporum viridiflorum, Prunus africana, Maytenus arbutifolia, Myrsine africana and Scolopia theifolia. Zerihun Woldu and Backeus (1991) describe this shrub land type to be a secondary community which has replaced the forest vegetation that gradually disappeared from the highlands.

\section{CONCLUSION AND RECOMMENDATIONS}

The Floristic description of Denkoro forest reveals the presence of high species diversity. Of the species recorded from the forest, 11 species are endemics that have been recorded in the red data list of IUCN, and 8 species identified as indicator species for forest disturbance.

Identification and description of the six community types in the forest revealed signs of heavy degradation in all, implying that the forest had been exposed to a past history of heavy exploitation. In addition, structural description of the forest indicated the predominance of small sized individuals. These observations assert Denkoro forest to be in a stage of secondary development at present.

Analysis of species population structure indicated a high variation among species population dynamics within the forest. Two 
generalized groups have been observed: species with a good capacity for regeneration, and species with a very poor regeneration or none at all.

Phytogeographic description of Denkoro forest asserts the presence of an undifferentiated Afromontane forest. A sub-Afroalpine vegetation that is represented with a clear Ericaceous belt, although not investigated in the present study, lies above the forest.

To ease the present human influence on the natural forest, and for a future management of the forest on a sustainable basis, the following recommendations are made:

$>$ Participatory forest management programs should be introduced so that local communities assume responsibility for the management and conservation of the forest, and end up as the beneficiaries of economic benefits ensuing from these activities,

$>$ Creating awareness, through extension programs, on the multiple use of forest resources and forest ecosystems,

$>$ Agro forestry practices should be introduced and encouraged so that local communities can obtain multiple uses out of it,

$>$ Natural regeneration of species in the forest can be facilitated through reduced grazing/browsing pressure,

$>$ Cattle rearing, a basic livelihood in the area, should be carried out commensurate with the carrying capacity of the environment,

$>$ The planning and management of forests can be assisted with research findings, and therefore, more basic and applied research should be encouraged.

\section{ACKNOWLEDGMENTS}

We would like to acknowledge the Swedish International Development Agency (IDA) for the financial support received through the Research Program on the Sustainable Use of Dry land Biodiversity (RPSUD).

\section{REFERENCE}

1. Edwards, S., Mesfin Tadesse and Hedberg, I. (eds) (1995). Flora of Ethiopia and Eritrea. Vol. 2, part 2. Addis Ababa University, Addis Ababa, 456 pp.

2. Edwards, S., Mesfin Tadesse and Hedberg, I. (eds) (1997). Flora of Ethiopia and Eritrea. Vol. 6. Addis Ababa University, Addis Ababa, 586 pp.
3. Edwards, S., Mesfin Tadesse and Hedberg, I. (eds) (2000). Flora of Ethiopia and Eritrea. Vol. 2, part 1. Addis Ababa University, Addis Ababa, 532 pp.

4. EFAP (1994). Ethiopian Forestry Action Program. EFAP, Addis Ababa.

5. Friis, I. (1986). Ethiopia in regional phytogeography. Symb. Bot. Ups. 26:68-85.

6. Friis, I. (1992). Forest and Forest Trees of Northeast Tropical Africa: their natural habitats and distribution pattern in Ethiopia, Djibouti and Somalia. Kew. Bull. Add. Ser. 15, 396 pp.

7. Grubb, P.J., Lloyd, J.R., Pennington, J.D. and Whitmore, T.C. (1963). A comparison of montane and lowland rain forest in Ecuador. I. The forest structure, physiognomy, and floristics. J. Ecol. 51:567-601.

8. Hamilton, A.C. (1974). Distribution patterns of forest trees in Uganda and their historical significance. Vegetatio 29:21-35.

9. Hailu Sharew (1982). An ecological study of a forest in Jemjem, Sidamo. MSc thesis, Addis Ababa University. Addis Ababa, Ethiopia.

10. Hedberg, I. and Edwards, S. (eds) (1989). Flora of Ethiopia. Vol. 3. Addis Ababa University, Addis Ababa, 659 pp.

11. Hedberg, I. and Edwards, S. (eds) (1995). Flora of Ethiopia. Vol. 7. Addis Ababa University, Addis Ababa, 420 pp.

12. Hedberg, O. (1951). Vegetation belts of the East African Mountains. Sven. Bot. Tidskr. 45:140-202.

13. Hill, M.O. (1979). TWINSPAN. A FORTRAN program for arranging multivariate data in an ordered twoway table classification of individuals and attributes. Cornell University, Ithaca, NY.

14. Hurni, H. (1985). Erosion - Productivity - Conservation System in Ethiopia. In: Proceedings of $4^{\text {th }} \mathrm{In}$ ternational Conference on Soil Conservation, Venezuela, pp. 3-9.

15. Kebrom Tekle (1998). Ecological rehabilitation of degraded hill slpoes in Southern Wello, Ethiopia. Comprehensive Summaries of Uppsala Diss. Fac. Sc. and Tech.363:1-36.

16. Kebrom Tekle, Backeus, I., Skoglud, J. and Zerihun Woldu (1997). Vegetation on hill slopes in Southern Wello, Ethiopia: Degradation and regeneration. Nord. J. Bot. 17:483-493.

17. Kumlachew Yeshitila and Tamrat Bekele (2002). Plant community analysis and ecology of Afromontane and transitional rainforest vegetation of southwestern Ethiopia. SINET: Ethiop. J. Sci., 25(2):155-175.

18. Lind, E.M. and Morrison, M.E.S. (1974). East African Vegetation. Longman, London, 257 pp.

19. Lisanework Nigatu (1987). An ecological study of the vegetation of the Harenna forest. MSc thesis, Addis Ababa University. 
20. Logan, W.E.M. (1946). An introduction to the forests of Central and Southern Ethiopia. Imperial Forestry Institute, University of Oxford. Inst. Paper No. 24, $58 \mathrm{pp}$.

21. Mesfin Tadesse (1990). An Illustrated Guide to the Trees and Shrubs in the Red Cross Project (UMCC-UPP) areas in Wello, Ethiopia. Ethiopian Red Cross Sodety, Addis Ababa, 181 pp.

22. MoPed (1993). Ministry of Planning and Development. A Preliminary Survey on Utilization and Conservation of Natural Resources in Southern Wollo, Dessie, 152 pp.

23. Pichi-Sermolli, R.E.G. (1957). Una carta geobotanica dell' Africa Orientale (Eritrea, Ethiopia. Somalia). Webbia 12:15-132.

24. Sebsebe Demissew (1998). A Study of the Vegetation and Floristic Composition of South Wello, Ethiopia. Journal of Ethiopian Studies 31(1):159192.

25. Tamrat Bekele (1993). Vegetation and ecology of Afromontane forests on the central plateau of Shewa, Ethiopia. Acta phytogeogr. Suec. 79, 64 pp.
26. Tamrat Bekele (1994). Phytosociology and ecology of a humid Afromontane forest on the Central Plateau of Shewa, Ethiopia. J. Veg. Sci. 5:87-98.

27. Tesfaye Bekele (2000). Plant population Dynamics of Dodonaea angustifolia and Olea europaea ssp. cuspidata in Dry Afromontane Forests of Ethiopia. Compr. Summ. Uppsala Diss. Fac. Sc. Techn. 559:1-47.

28. Tewolde Berhan Gebre Egziabher (1989). The Environmental Variables which led to the ecological crisis in Ethiopia. Coenoses 4:61-67.

29. van der Maarel, E. (1979). Transformation of coverabundance values in phytosociology and its effects on community similarity. Vegetatio 39:97114.

30. van der Maarel, E., Espejel, I. and Moreno-Casasola, P. (1987). Two-step vegetation analysis based on very large data sets. Vegetatio 68:139-143.

31. Walter, H. (1985). Vegetation of the Earth and Ecological Systems of the Geo-biosphere. Springer-Verlag. New York, 274 pp.

32. Zerihun Woldu and Backeus, I. (1991). The shrubland vegetation in western Shewa, Ethiopia and its possible recovery. J. Veg. Sci. 2:173-180. 